\title{
Dual Affinity in V. S. Naipaul's Half a Life
}

\author{
${ }^{1}$ Subismita Lenka, ${ }^{2}$ Bhabani S. Baral \\ ${ }^{I}$ Asst. Professor Dept. Humanities \& Social Sciences Institute of Technical Education \& Research Siksha ' $O$ ' \\ Anusandhan University Jagamohan Nagar, \\ ${ }^{2}$ Professor Dept. Humanities \& Social Sciences Institute of Technical Education \& Research Siksha 'O' \\ Anusandhan University Jagamohan Nagar, Jagamara, Bhubaneswar-751030
}

Despite the hullabaloo about his nativity, attitude and education, the fact remains that V.S.Naipaul as a writer belongs to the Indian diaspora. Apparently, his description of India in the three travelogues as dark, wounded and mutinous does not go down well with the readers in this country. But that description is not totally incorrect and beneath that lies obviously the affinity for his roots. Bruce King is right when he says:

While Naipaul is a rationalist, secular, a strong believer in Western individualism and scepticism, he is emotionally attracted towards Indian fatalism, passivity and philosophical notions of the world as illusion. Both world views vie with each other in his writings.(pp.7-8)

Naipaul is thoroughly critical of Indian novelists over dependence on myths and lack of concern for the present condition of men. In An Area of Darkness he writes:

The novel is of the west. It is a part of that western concern with the condition of men, a response to the here and now. In India thoughtful men have preferred to turn their back on the here and now. (p.214)

However, the novel that Naipaul writes is not strictly a novel in the western sense of the term. According to Bruce King “.......he created his own, original, blend of fiction, reportage and autobiography” and again "he was at the forefront of bringing together various kinds of writing in fiction."(p.5) These various kinds of writing that go into the writing of his fiction also includes mythology in small doses. Besides mythology, he also incorporates modern variants of myth such as pre-figurations and intertextuality, sometimes copiously, in his fiction. Again it must not be forgotten here that a myth or its modern variants in literature may be used either in affirmation or in denial i.e. a myth may be used as an ideal and point of reference or one may espouse the cause of a different ideology as a reaction to a particular myth. A pointed analysis of Half a Life vividly brings out the mythological motif behind this non-fiction novel of Mr Naipaul.

John J. White in his stimulating book Mythology in The Modern Novel distinguishes a mythological work from what is called a mythical one and maintains that a mythical novel is one which is commonly associated with a dynamic quality, a "mana" seldom present in a work that he describes as mythological. Being divested of this kind of religious connotation mythology becomes an equivalent of any ordinary allusion and this is further reinforced by his use of the term "pre-figuration" instead of myth. He considers the use of myth as a technique and explains that a myth introduced into a novel can prefigure and anticipate the plot in several possible ways: Ordinarily the term "pre-figuration" means "coming before" and it offers a system of comments on modern events. Liberally extending the term he maintains that even these pre-figurations include literary plot “pre-figurations" such as Shakespeare's plays in Aldous Huxley's Brave New World, Chekhov's The Seagull and in Macdonald Harris's Trepleff. As it is well known, many novels refer to other works and discourses. As a genre, the novel consciously gives space to other works. This is what nowadays goes by the name of intertextuality and this is a feature which Bakhtin appreciated in the novel. Going back to the middle ages; it was often seen, the relationship to another's word was equally complex and ambiguous. The boundary lines between someone else's speech and one's own speech were flexible, ambiguous, often deliberately distorted and confused. Certain types of texts were constructed like mosaics out of the texts of others. The term intertextuality, writes Pramod K. Nayar, "refers to the allusions, references to other works, echoes, quotes and citations and even plagiarized sections of a work". (p.30)

$* * * * * * * *$

It is true that Hindu religious mythology, as it is used in novels of Naipaul is not of the purest kind. As Fawzia Mustafa writes, "The very crossing of the ocean of the laborers from India precluded the religion's transportation in any orthodox sense, and its subsequent practice by migrants is, theoretically, necessarily compromised.”(pp.52-3) 
The religion of the displaced and half-made people may have been compromised but that certainly does not warrant acerbic attacks of the kind that only a Naipaul can make. It is no wonder that even a commentator like Edward Said who considers Naipaul a "remarkable and gifted writer," simultaneously rejects his ideas:

So great has the pressure of western ideas become in Naipaul that any sympathetic feelings he might have had for the things he sees have been obliterated. There is no life in what he writes about - only hard lunacy, despair. (p.102)

Indeed Naipaul, the unsparing critic has many bitter things to say about anything that is Indian, specially that is based on myth or fantasy. Though no admirer of Indian ways of life, he justifiably lauds the traditional Indian attitude to sex and sensuality. True, in Half a Life his protagonist Willie Chandran is dismissed by the prostitute with the words: "Fuck like an Englishman"(p.121) As it is mentioned earlier, this is a novel with an autobiographical content and this leads the author to candidly confess:

We are all born with sexual impulses, but we are not born with sexual skill, and there are no schools where we can be trained. People like me have to fumble and stumble on as best they can, and wait for accidents to take them to something like knowledge. (p.189)

Obviously, Willie did not possess this knowledge. Naipaul takes this opportunity to talk about the traditional Indian view of sex and how in course of time this has become a taboo for most Indians. Santwana Haldar writes: "Through Willie's views on sex Naipaul expresses some of his own. One such view is that the ancient Indian philosophical practical way of dealing with sex was destroyed by the Muslim invasion and the thing became worse during the British period. Sex used to be a taboo and stood on the way of one's self-assertion. Willie's lack of self-assertion was also related to this taboo."(p.241) However, it is perhaps worthwhile to mention here that the attitude of traditional Indians to love and sex is opposed to that of religion and ethics. The traditional Hindu approach glorifies love and sex and portrays "Shringara Rasa" as the ideal emotion for people in love. Adya Rangacharya in his essay Sex and Indian Literature writes:

It is enough to note that an early and well known proponent and commentator of the theory describes the distinctive feature of 'Rasa' as the quality of 'losing oneself' in the enjoyment. It is not pleasure or joy or even ecstasy as such but the state where one loses one's identity. This is exactly a feeling that distinguishes sexual experience. This particular feeling in literary appreciation is called 'Rasa' a word which has no equivalent in English. It is no surprise in view of the origin of the conception, to find that Rasa of Love (Shingara) is called the king of all the Rasas. Sex experience is at the root of the conception. (p.144)

How different is this from the Muslim purdah (veil) system which keeps love and sex under wraps and Christian sense of guilt which arises because man is a fallen creature.

The opening section of the novel spanning fifty-six pages and entitled as A Visit from Somerset Maugham sets the tone for the entire novel. A peep into some of the incidents of this chapter only reinforces the belief that Naipaul as a writer is polemical in nature and hence, is able to see only one half of life. Through the pages of the section, Naipaul creates the character of Willie's father who is said to have influenced the saintly figure in Somerset Maugham's The Razor's Edge. Larry of Somerset Maugham is impressed by the Indian saint Shri Ganesha who purifies the mind but Naipaul, the author is no taker for this piece of traditional wisdom. Rather he accuses, writes Haldar, "the Indians hankering after the stamp of foreign approval."(p.232)

It may be mentioned here that Naipaul's portrayal of Indian reality is portrayal of half-a-life only. Nowhere an appreciation of Indian mythico-religious reality finds a place. And it is perhaps appropriate to quote here what Nidhi Tiwari says about the matter:

If an artist imitating life as Aristotle stated, should the artist imitate it only 'as it is?' The artist can easily depict it 'as it ought to be' which can serve a therapeutic purpose for the cultural neurasthenia which casts a dark shadow all over the globe. (p.275)

Obviously, Naipaul the iconic writer is falling a prey to "the commercial drive which is rampant globally" and "is reaping the harvest of India bashing."(p.278)

The second incident, the marriage of Willie's father to a harijan girl, strangely enough, raises the eyebrows of Naipaul, through his writings, advocates a cosmopolitan world with an egalitarian outlook, it is to be found here in the action of Willie's father who was imbued with the teachings of Gandhi which envisaged a classless society in independent India. But that even angers Sir Vidia, the writer. May be because of the idealism involved. But when one's idealism is as per the needs of a just society, the criticism of the writer seems to be unwarranted. It is another matter that initially Willie's father was a reluctant spouse and he experienced what Alpana Mishra calls "the ambivalent pleasure of embracing an untouchable woman."(p.185) May be Naipaul is critical of this kind of hypocrisy but that is also understandable. In India, discarding the mythico-religious status of various castes is a task of tall order and Willie's father, despite his idealistic leanings, takes some time to adjust to the situation. The negative description of the girl in the novel makes the job difficult still:

Her very dark top lip slipped slowly - with the wetness of a snail, I thought - over her big white teeth. For the first time I saw she used powder. There was a thin white bloom on her 
cheeks and forehead it made the black skin matt, and you could see where the powder ended and the shiny skin showed again. I was repelled, ashamed, moved. (p.13)

He does adjust with the situation. In fact, in tune with his idealistic leanings; he is moved at the sad plight of this downtrodden girl. And the result of all this is there for everybody to witness. Despite the Gandhian view of brahmacharya, two children, Willie and Sarojini were born. He even names the boy after Somerset Maugham, the famous writer, a votary of Indian philosophy and Sarojini Naidu, the poet-cum-freedom fighter from India who is a pillar of Indian culture and philosophy. Castigating this courageous decision of Willie's father taken against all odds, indeed does not speak well of Naipaul, the writer. His ironic comments in this situation, is a sign of his parochial and jaundiced vision.

As it has been categorically mentioned in the Introduction, Naipaul the writer despite his open aversion to myths makes use of mythological motifs in the form of pre-figuration and intertextuality. Predictably enough, most of these earlier texts are ironically used to drive home his point of view. As a writer Naipaul most often crosses the barrier of the literary form and makes use of history and autobiography in the body of a novel. At the beginning of Half a Life Naipaul calls it an invention suggesting thereby that in spite of influences of all kinds, the authorial voice is something discernible. Michael Bakhtin describes novel as essentially polyphonic or dialogic and hence, it is basically different from monological discourses of all kinds. In Half a Life the first section is entitled as "A Visit from Somerset Maugham". According to Florence D'Souza it is nothing but a satirical rendition of R.K.Narayan's famous novel The Guide. In Narayan's novel the tourist guide Raju, takes refuge in the courtyard of a temple and starts a new career "as a holy man, receiving alms and donations in exchange for his wise advice." (p.54) In Half a Life the elder Chandran stays put in the temple courtyard which amounted to "turning his back on a glittering career, living as a mendicant on the alms of the poorest of the poor". (p.3)The irony involved in the use of Narayan pre-figuration is clearly evident in another situation. The relationship between the Railway Raju and dancer Rosie is platonic while in case of Naipaul it is an "iconoclastic relationship, deliberately outside the strict Brahmanical norms for endogamous marriage, between elder Chandran and his low-caste wife."(p.55)

Another important example of intertextuality in V.S.Naipaul is his use of Mulk Raj Anand's The Bubble. As an intellectual he was a close follower of Joseph Conrad. As Binod Mishra writes:

Like Conrad, he too knew that every novelist must begin by creating for himself a world, great or little in which he could 'honestly behave' and this world cannot be made otherwise than in his own image.(p.130)

The days of darkness (An Area of Darkness) are over. The writer Naipaul is no more there in a stifling situation. Rather increasingly he understands the fact that self-consciousness cannot come without proper self-analysis. And as Binod Mishra points out:

The essence of existentialism is transcendence which is a leap from the self to the absolute....... Krishnan in Anand's The Bubble and Willie in Half a Life symbolize the act of will and decisive engagement. Those critics who blame Naipaul for profaning the 'exalted vocation of a writer' speak only the half-truth. Naipaul's philosophy is the philosophy of transformation. It is a philosophy of hope, harmony and happiness............ Willie's journey to meaning and maturity reminds us of Krishan's. (p.137)

It is often believed that most of the Naipaul protagonists are unanchored souls. The variegated experience of one's life is dependent on human whims, desires and attitudes. Hence, finding a centre for all this is ordinarily considered to be difficult. Added to all this, is their post-colonial status. But here also there is the cementing factor. In this context the words of fellow writer Derek Walcott (Noble Lecture, 1993) seem to hold the key:

Break a vase, and the love that resembles the fragments is stronger than the love which took its symmetry for granted when it was whole....... Antillean art is this restoration of our shattered histories, our shreds of vocabulary, our archipelago becoming a synonym for pieces broken off from the original continent.

The dual affinity and the broken history not only adds charm and meaning to the post-colonial experience, it also make use of what Noam Chomsky feels, the bio-physical structure below the threshold of mind to deduce a unified language from the aforesaid variegated experience. In the language of Chomsky "a mass of schematisms, innate governing principles, which guide our social and intellectual and individual behavior" (p.136) is also responsible for bringing unity to the composition of a writer. This also inevitably leads us to believe that despite the polemics and irony involved, his novels give us a positive vision. Peter Hughes is right when he says,

....... I want to step sideways to compare the remarkable tone of Naipaul's prose with that of some other writers, mostly American, who share with him the power to underwrite the disorder and poignancy of the world. He is in the end, and has been almost from the start, one of those writers who convey intensity not by raising but rather by lowering their 
voices; who give a new dimension to friction by seeming to undercut its claims. Naipaul to my mind stands and rises to greatness as or writer because his prose has such precision and strength. His feeling for language, his mastery of style, show that Gibbon was right. However belated and Byzantine the cultural conditions may be, however sunk in servitude and depression, the discourse of literature can still restore to the human spirit what might otherwise seem lost beyond recall. (p.93)

It is perhaps pertinent to point out that in spite of Naipaul's strong affinity to realism and allergy for mytho-poeic imagination, the undercurrent of mythological motif is very strong in him. This is even more so on the face of a critical onslaught made by Irving Howe in his book Politics and the Novel. Howe calls himself one of the "uneasy admirers of Naipaul and explains:

Uneasy because of his surplus of disgust and paucity of tenderness, but an admirer because he writes with a strict refusal of romantic moonshine about the moral charms of primitives or the virtues of blood stained dictators. (p.265)

On the surface of it, Naipaul may have rejected the moral charms of the primitives and enhanced his image as a realistic and cosmopolitan writer but a close scrutiny reveals that he is not a writer who is oblivious of the other half of life. As a diasporic writer he has the dual affinity with both the countries and in fact, with several countries and hence, his portrayal of in Half-a-Life is not an incomplete one as it is often made out to be. The novel in question here, in the fitness of things, makes use of modern variants of myths i.e. pre-figuration and intertextuality to confer that wholeness of vision which is ordinarily denied to Naipaul, the writer.

Critics like Prof. Colon tell us as to how "Naipaul's use of memory to create a myth of origin through an Indian character, William Somerset Chandran" (p.168) is instrumental for understanding a novel like Half a Life. Very many things have been said about Naipaul's use of history. But at times his sense of history is only skin deep. At least that is what Willie Chandran makes us believe:

At home he had read the newspapers, but he read them in his own way. He had learned to shut out the main stories, the ones with far-off wars or election campaigns in the United States that meant nothing to him....... So, just as on the ship Willie was able to watch without seeing and hear without listening. Willie at home for many years read the newspapers without talking in the news. (p.54)

It may be averred without hesitation here that this "manipulation and appropriation" of memory and history both has the sanction of Naipaul, the author. And the reasons are not far to seek. This is the first explicit attempt of Willie to scuttle what Naipaul calls non-fiction novel writing. Secondly, from the mytho-poeic point of view, fear of history is necessarily embedded in the Indian psyche.

History believes in the mundane, the finite but for an Indian life does not come to an end with the death of the physical body. Accordingly, it is atman which has an essence of brahman and hence, is immortal. By trying to ignore certain vicissitudes of history, Willie is only trying to be true to the author's Indian origin. Naipaul writes:

No one he met, in the college or outside it, knew the rules of Willie's own place, and Willie began to understand that he was free to present himself as he wished. He could, as it were, write his own revolution. The possibilities were dizzying. He could within reason, re-make himself and his past and his ancestry. (p.60)

And this possibility is not for Willie alone but also for his creator, V.S.Naipaul. At least it is a sign that Sir Vidia has ultimately made certain compromises, his self-avowals notwithstanding. Non-fiction novel writing has yielded place to something that is fictional, may be, myth in undertones.

Willie's remaking of the past and ancestry becomes self-evident in an interesting episode of the novel Half a Life. When he was a boy of ten a rich merchant who was generous enough to donate to religious charities came to his father. With his immature boyish mind he was given to understand that the merchant was "shameless in his private life", he "reached some crisis in his life" and hence he was "in a difficult situation".(p.206) Later Willie came to know the merchant claimed himself to be "like King Dasaratha".(p.206) This enraged Willie's father because he thought it audacious on the part of the merchant to compare himself to gods. The merchant rectified himself a little and said, "perhaps I am not quite like Dasaratha. He had three wives. I have two."(p.206) At that point of time it was not only Willie's father but also Willie who "found out about the shamelessness of the merchant's life"(p.207) and he was equally appalled.

Discarding the myth of King Dasaratha may have come very easy to the boy Willie. But not so to Willie Somerset Chandran some twenty-five years after. And he is fully conscious about that. A liberal individualistic life-style may be order of the day according to a progressive Naipaul but that was also the order of the mythical times. It is no wonder that Willie embraces this progressive yet mythical outlook when he picks up two women, just like King Dasaratha perhaps. Naipaul writes:

To have two wives and two families was two violate nature. To duplicate arrangements and affections was to be perpetually false. It was to dishonor everyone; it was to leave everyone in quicksand. 
This was how it had looked to me when I was ten. Yet every day I faced Anna without shame, and whenever I saw Luis, Graca's husband, I dealt with him with a friendship that was offered out of gratitude for Graca's love. (p.207)

Hence, the stringing allegation of critics that Naipaul's Half a Life portrays only half of Indian life and not the full one in fact fails to hold good. In general Sir Vidia may have considered Indian a wounded civilization but grown up Willie Somerset Chandran in his acceptance of the reality contained in the myth of Dasaratha unequivocally confirms Naipaul's dual affinity. Thus, Nidhi Tiwari's contention about him stands nullified with a great degree of certainty. Tiwari writes:

Willie's decision to discard his roots reveals what Sir Vidia fails to see in India, not 'A

Wounded Civilization' only, but a country that is rich in several aspects with a capacity to

heal all wounds - a capacity to see life as not 'Half a Life' but as 'Poorna'. Can you rise

out of the banality in which you've trapped yourself, Sir Vidiadhar? (p.278)

But this assertion that the novel is only the duplication of one half of life, certainly does not cut ice with a sensible reader who reads between the lines and gets the real essence of what the writer means to say. In a way, it like T.S.Eliot The Waste Land gives the readers an overall negative vision but an inkling of the positive aspects of life is deeply ingrained in the same. From that standpoint, the novel which is a unique blend of fiction, reportage, autobiography and myth achieves what a similar book in the hands of a lesser writer can never hope to and hence, it categorically proves the title of the novel to be a misnomer.

\section{$* * * * * * * * * *$}

\section{Works Cited}

[1]. Anand, Mulk Raj. The Bubble. Arnold-Heinemann, 1984. Print.

[2]. Chomsky, Noam. 1974.

[3]. Colon, Aida Luz Rodriguez. "V.S.Naipaul's Half a Life: Memory and the Myth of Origin.” V.S.Naipaul: Critical Essays. Ed. Mohit K. Ray. New Delhi: Atlantic, 2005. 167-180.

[4]. D' Souza, Florence. "V.S.Naipaul's Quest for a Voice of his own: The Enigma of Arrival and Half a Life." V.S.Naipaul: Fiction and Travel Writing. Eds. Rajeshwar Mittapalli and Michael Hensen. New Delhi: Atlantic, 2008. 45-64.

[5]. Haldar, Santwana. "V.S.Naipaul's Half a Life: The Colonial Context and Some Postcolonial Issues." V.S.Naipaul: Critical Essays. Ed. Mohit K. Ray. New Delhi: Atlantic, 2005. 226-249.

[6]. Howe, Irving. Politics and the Novel. New York: Colombia University Press, 1992. Print.

[7]. Hughes, Peter. V.S.Naipaul: Contemporary Writers. London: Routledge, 1988. Print.

[8]. King, Bruce. V.S.Naipaul. New York: Macmillan, 2003. Print.

[9]. Maugham, W.Somerset. The Razor's Edge. London: Pan Books, 1976. Print.

[10]. Mishra, Alpana. "V.S.Naipaul's Half a Life: A Critical Study." V.S.Naipaul: Critical Essays. Ed. Mohit K. Ray. New Delhi: Atlantic, 2005. 181-225.

[11]. Mishra, Binod. "Return and Reconciliation in V.S.Naipaul's Half a Life." The Atlantic Critical Review, 3.2 (2004): 129-138. Print.

[12]. Mustafa, Fawzia. Cambridge Studies in African and Caribbean Literature: V.S.Naipaul. New York: Cambridge University Press, 1995. Print.

[13]. Naipaul, V.S. Half a Life. London: Picador, 2011. Print.

[14]. Naipaul, V.S. An Area of Darkness. Penguin, 1968. Print.

[15]. Narayan, R.K. The Guide, Madras: Indian Thought Publication. 2002. Print.

[16]. Rangacharya, Adya. "Sex and Indian Literature." Indian Literature 34.5 (1991). 139-146. Print.

[17]. Said, Edward. "Bitter Dispatches from the Third World." Reflections on Exile. London: Penguin Atlantic Books, 2001.

[18]. Tiwari, Nidhi. "V.S.Naipaul's Half a Life: A World of Cultural Neurasthenia sans Therapy." V.S.Naipaul: Critical Essays. Ed. Mohit K. Ray. New Delhi: Atlantic, 2005. 271-278.

[19]. Walcott, Derek. Nobel Lecture. Atlantic Critical Review, 1993.

[20]. White John J. Mythology in the Modern Novel: a Study of Pre-figurative Techniques. Princeton, 1971. Print. 